\title{
KEBIJAKAN PENDIDIKAN ANAK BERKEBUTUHAN KHUSUS DI SURABAYA DALAM PERSPEKTIF ISLAM
}

\author{
Rio Febriannur Rachman \\ Universitas Airlangga Surabaya, Indonesia \\ Email : rio.febriannur.rachman-2018@fisip.unair.ac.id
}

\begin{abstract}
Artikel ini membahas tentang program pendidikan dasar anak-anak berkebutuhan khusus yang ada di Surabaya. Program tersebut dijalankan oleh Dinas Pendidikan Kota Surabaya melalui pengadaan Pusat Layanan Disabilitas atau PLD yang lokasinya tersebar di bagian Barat, Timur, Utara, Selatan, dan pusat kota Surabaya. Pada 2009, anakanak yang menyandang kebutuhan khusus diberi fasilitas belajar bersama dengan mereka yang tidak berkebutuhan khusus melalui sekolah inklusi. Di sekolah inklusi itu terdapat Guru Pembimbing Khusus (GPK) yang berlatar belakang sarjana pendidikan luar biasa dan sarjana psikologi. Pada 2016, program sekolah inklusi yang sudah berjalan itu dikuatkan dengan keberadaan PLD. Program ini merupakan salah satu bukti kalau Surabaya serius memberi pengayoman dan pelayanan bagi masyarakat dari berbagai latar belakang atrau lapisan masyarakat. Sebagai upaya mengimplementasikan semangat Undang-Undang Dasar 1945 yang berazas keadilan sosial, termasuk di bidang pendidikan. Teori yang dipakai dalam artikel ini berhubungan dengan pendidikan dasar, konseling (karena anak-anak berkebutuhan khusus memerlukan intervensi ini), dan kebijakan publik. Metode yang digunakan adalah kualitatif dengan pendekatan kajian pustaka. Artikel ini membahas bagaimana kebijakan publik PLD dihubungankan dengan konsep pembangunan berkelanjutan yang digariskan Perserikatan BangsaBangsa dan konsep kemaslahatan umat yang ditekankan oleh ajaran Islam. Hasil dari studi ini menunjukkan, program PLD memiliki kesesuaian dengan pembangunan sosial berkelanjutan dan semangat menumbuhkan kemaslahatan umat. Dengan demikian, program ini layak untuk terus dilanjutkan, tentu saja dengan keterbukaan untuk melakukan pembenahan di kemudian hari, dan cocok untuk direplikasi di daerah-daerah lain.
\end{abstract}

Kata Kunci : Pendidikan, Anak Berkebutuhan Khusus, Kebijakan Publik, Kemaslahatan Umat.

\section{Pendahuluan}

Undang-Undang Sistem Pendidikan Nasional menggariskan bahwa

pendidikan bertujuan mencerdaskan kehidupan bangsa dan 
mengembangkan Sumber Daya Manusia (SDM) di Indonesiaํ. Bangsa dan SDM itu tidak menyasar kelompok tertentu. Secara lebih luas, pendidikan nasional mesti menyentuh semua lapisan masyarakat. Dalam sejumlah literatur disebutkan, pendidikan merupakan proses pengubahan cara bertingkah laku, sikap, dan bertutur seseorang atau sekelompok orang ${ }^{2}$.

Dengan maksud mendewasakan manusia sehingga bisa menjadi pribadi yang lebih baik. Dalam kitab Ta'lim Muta'allim, konsep pendidikan dijelaskansecara gamblang dengan menghubungkannya pada seluk-beluk adab seseorang baik tatkala belajar maupun mengajar ${ }^{3}$. Bila mengacu pada kaidah bahasa Arab, pendidikan kerap disebut dengan istilah tarbiyah yang berasal dari kata robba. Abul A'la al-Maududi menuturkan, kata rabbun terdiri dari "ro" dan "ba", yang tidak sekadar bermakna pendidikan tetapi juga mencakup arti "kekuasaan, penyempurnaan, dan pertanggung jawaban" 4 . Konsep makna pendidikan lain adalah Ta'lim, sebagai masdar dari kata 'allama. Artinya, pengajaran yang sifatnya adalah penyampaian atau pemberian ${ }^{5}$.

Bertolak dari Undang-Undang Negara Republik Indonesia dan betapa pentingnya makna pendidikan bagi bangsa dan SDM di negara ini, Pemerintah Kota ingin terus memberikan pelayanan maksimal bagi pendidikan warga. Tak terkecuali pada anak-anak dan remaja yang telah diberikan ruang konseling demi menuntaskan problematika mereka ${ }^{6}$.

${ }^{1}$ Moh. Soardi dkk, 2017, Dasar-dasar pendidikan, Yogyakarta:PT. Parama Ilmu, 50.

${ }^{2}$ Nur Kholis, 2013 ,"Pendidikan dalam upaya memajukan teknologi", Jurnal kependidikan, Vol 11, No. 1, November, 24.

${ }^{3}$ Mahsun, Moch \& Danish Wulydavie Maulidina. 2019. “Konsep Pendidikan Dalam Kitab Ta'limul Muta'allim Karya Syekh Al-Zarnuji Dan Kitab Washoya Al-Aba' LilAbna' Karya Syekh Muhammad Syakir". Bidayatuna: Jurnal Pendidikan Guru Mandrasah Ibtidaiyah, 2 (2), halaman 44-77

4 Sudandi, 2015, Pengantar studi Islam, Yogyakarta:Media Tera, 154.

${ }^{5}$ Moh.Roqib, 2005, Ilmu pendidikan Islam, Yogyakarta:Lkis, 14.

${ }^{6}$ Rio Febriannur Rachman. 2019. "Implementasi Kebijakan Pusat Konseling Anak Dan Remaja Di Surabaya". Al-Tazkiah : Jurnal Bimbingan Dan Konseling Islam, 8(2), 77-91 
Termasuk pula, warga yang tergolong anak-anak berkebutuhan khusus7. Pada tahun 2009, Surabaya sejatinya sudah mendirikan sekolah-sekolah inklusi. Mereka yang memiliki kebutuhan khusus bisa belajar dengan siswa-siswi tidak memiliki kebutuhan khusus. Sekolah itu memunyai Guru Pembimbing Khusus (GPK) yang merupakan lulusan sarjana pendidikan luar biasa dan sarjana psikologi.

Demi mengoptimalkan layanan pendidikan bagi anak-anak berkebutuhan khusus, pada 2016, Pemerintah Kota Surabaya melalui Dinas Pendidikan meluncurkan program Pusat Layanan Disabilitas atau PLD. Program ini menguatkan program untuk warga berkebutuhan khusus lain, misalnya, yang terkait dengan magang kerja ${ }^{8}$. PLD secara spesifik menargetkan pendidikan dasar anak-anak berkebutuhan khusus. PLD tersebar di wilayah Surabaya Pusat, Selatan, Utara, Timur, dan Barat ${ }^{9}$. Menurut data hingga April 2019, terdapat 419 klien anak berkebutuhan khusus yang telah diberi intervensi secara intensif. Jumlah itu belum termasuk warga Surabaya yang dilayani secara tentatif atau jadwal pertemuannya dengan petugas pendidik/pembina PLD tidak serinci mereka yang mendapat intervensi intensif. Bila dihitung jumlah kegiatan intervensi petugas sejak PLD berdiri hingga April 2019, tak kurang sudah 2.128 aktifitas yang dilakukan.

Masing-masing PLD di tiap wilayah, memiliki sejumlah petugas. Mereka melakukan pendidikan dan pembinaan pada anak-anak berkebutuhan khusus (ABK). Mereka juga melakukan pendekatan pada keluarga ABK dan memberikan mereka pemahaman tentang persoalan

\footnotetext{
7 Bagian Organisasi Pemerintah Kota Surabaya. 2019. "Pulau Emas". Dapat diakses di https://organisasi.surabaya.go.id/home/file/pelayanan\%20publik/masuk\%20web/pr oposal \%20pulau \%20emas.pdf

8Zainil Ghulam. 2020. “Implementasi Kebijakan Magang Dan Konseling Warga Berkebutuhan Khusus Di Surabaya". Dakwatuna: Jurnal Dakwah dan Komunikasi Islam, 6, (1), halaman 75-87,

${ }^{9}$ Surabaya.go.id. 2018. "PLD Lima Wilayah untuk Tingkatkan Layanan Pendidikan Inklusi". Dapat diakses di https:// surabaya.go.id/id/berita/46197/pld-lima-wilayahupaya-tingkatk
} 
yang dihadapi ABK. Fokus utamanya, adalah ABK dan keluarga yang berasal dari ekonomi lemah. Logikanya, mereka yang memiliki ekonomi kuat, telah menyekolahkan ABK ke tempat-tempat khusus. Nah, mereka yang dari ekonomi lemah ini yang menjadi konsentrasi PLD.

Ada banyak layanan di PLD, antara lain, anak yang awalnya kesulitan belajar karena sukar fokus dalam berpikir, diberi arahan dan intervensi konseling agar mudah menyerap pelajaran. Misal lainnya, ABK yang memiliki keterbatasan gerak fisik, bahkan sukar untuk menggerakkan jemari atau mengangkat kepala, diberi terapi ${ }^{10}$. Sehingga, gerak mereka bisa lebih luwes. Pada gilirannya, mereka bisa melakukan kegiatan-kegiatan untuk keperluan mereka secara mandiri.

PLD juga memiliki program untuk melacak ABK, khususnya yang bukan termasuk siswa/siswi sekolah inklusi. Karena diperkirakan, di lingkungan Surabaya, masih ada ABK yang belum mendapat layanan pendidikan maupun pembinaan. Setidaknya, petugas di tiap PLD terdiri dari tiga pakar. Mereka adalah dua sarjana dari latar belakang pendidikan luar biasa dan satu orang sarjana dari ilmu psikologi. Mereka merupakan orang-orang berpengalaman yang sebelumnya tercatat sebagai GPK di sekolah-sekolah inklusi maupun Sekolah Luar Biasa(SLB).

PLD didirikan agar dapat memecahkan persoalan-persoalan yang menimpa $\mathrm{ABK}$, misalnya, tentang $\mathrm{ABK}$ yang belajar di sekolah noninklusi, tapi kebutuhan khususnya belum didapatkan. Bagaimanapun juga, masih banyak ditemui guru ataupun orangtua tidak paham secara detail poin kebutuhan-kebutuhan khusus ABK. Yang menarik, PLD berkoordinasi dengan kelurahan-kelurahan untuk melakukan "jemput bola" pada ABK di kampung-kampung Surabaya. PLD memiliki SDM maupun fasilitas pendukung. Ada pun tahapan intervensi yang dilakukan adalah konsultasi, identifikasi, assessement, dan intervensi.

\footnotetext{
10 Jawa Pos. 2017. "Bentuk Pelayanan Khusus Buat Penyandang Disabilitas". Dapat diakses di https://www.jawapos.com/nasional/pendidikan/07/02/2017/bentukpelayanan-khusus-buat-penyandang-disabilitas/
} 
Dilaksanakannya program di PLD ini memberikan peluang bagi mereka yang berkebutuhan khusus untuk mengembangkan diri. Terlebih, dalam pelaksanaannya, Dinas Pendidikan Surabaya bersinergi dengan pihak-pihak lain, seperti asosiasi atau perkumpulan para pakar konseling dan psikologi khusus ABK. Program yang mengandalkan sinergitas ini memang sudah kerap dijalankan oleh Pemerintah Kota Surabaya, dalam banyak bidang sasaran. Sebagai contoh, di program ekonomi kerakyatan Pahlawan Ekonomi11. Pada program ini, kerjasama erat dikerjakan dengan menggandeng banyak pihak, antara lain perusahaan-perusahaan dan industri kreatif. Segala tahapan dilaksanakan dengan membawa semangat Undang-Undang dan kultur masyarakat Surabaya yang sarat azas kekeluargaan ${ }^{12}$. Sebab, orang-orang Surabaya umumnyamemiliki rasa kepedulian yang tinggi.

Tulisan ini mengupas bagaimana kebijakan publik di bidang pendidikan dasar ABK diimplementasikan secara komprehensif di Surabaya melalui PLD. Konteks yang dipakai adalah kebijakan pemerintah Surabaya. Maka itu, teori kebijakan publik yang dipakai untuk menganalisis fenomena tersebut. Kebijakan publik merupakan struktur tatanan yang bisa berupa sistem, regulasi, atau mekanisme kegiatan yang dijalankan oleh pemerintah melalui segenap potensi, demi mencurahkan manfaat bagi masyarakat ${ }^{13}$. Dalam penelaahan tersebut, dihubungkan pula dengan konsep tujuan pembangunan berkelanjutan yang dicanangkan oleh Perserikatan Bangsa-Bangsa dan poin-poin kemaslahatan umat di lingkup ajaran Islam.

\section{Metode Penelitian}

\footnotetext{
${ }^{11}$ Rio Febriannur Rachman. 2019. “Optimalisasi Media Digital Berbasis Kemaslahatan Umat dalam Program Pahlawan Ekonomi Surabaya".Iqtishoduna: Jurnal Ekonomi Islam, 8 (2), 273-292

12 Soedarso, Soedarso, et al. Dinamika Multikultural Masyarakat Kota Surabaya. Jurnal Sosial Humaniora 6.1 (2013): 62-75.

${ }^{13}$ Anderson, James E. 1984. Public Policy Making. New York: Holt, Rinehart and Winston.
} 
Riset ini menggunakan metode kualitatif dengan pendekatan studi pustaka. Artinya, telaah yang dilakukan berdasarkan sumber perpustakaan untuk memperoleh dan mengolah data ${ }^{14}$. Materi diskusi dalam artikel ini adalah kebijakan publik di Surabaya berupa PLD yang dijalankan oleh Dinas Pendidikan Pemerintah Kota Surabaya. Data utama atau keterangan mengenai program ini didapatkan dari Bagian Organisasi Pemerintah Kota Surabaya. Kegiatan di PLD itu kemudian didiskusikan melalui sejumlah teori mengenai pendidikan, konseling, dan kebijakan publik. Setelah itu, dihubungkan dengan konsep Pembangunan Sosial Berkelanjutan yang digariskan oleh Perserikatan Bangsa-Bangsa dan konsep Kemaslahatan Umat yang disampaikan oleh ajaran Islam. Sumbersumber literatur lain juga digunakan demi memerkaya artikel ini. Semua bahan kepustakaan diolah untuk menggambarkan dengan jelas tentang bagaimana program PLD ini berjalan di Kota Surabaya.

\section{Kebijakan Publik Bersemangat Maqasid Syariah}

Ada sejumlah penjelasan tentang konsep kebijakan publik. Secara umum para pakar menjelaskan tentang apa pun yang dijalankan atau tidak dijalankan pemerintah demi memenuhi hajat hidup orang banyak ${ }^{15}$. Kebijakan publik diimplementasikan oleh elemen-elemen yang ada di pemerintahan, bisa di level paling bawah hingga level paling atas ${ }^{16}$. Maksud paling utama dari berjalannya kebijakan publik adalah menyuguhkan manfaat pada masyarakat di semua lapisan. Di Surabaya, ada banyak kebijakan yang sudah diimplementasikan dan terbukti bersumbangsih bagi masyarakat di bidang apa pun. Termasuk, di bidang

\footnotetext{
14 Zed, M. (2008). Metode Penelitian Kepustakaan. Jakarta: Yayasan Pustaka Obor Indonesia.

15 Thomas R. Dye. 1972. Understanding Public Policy. New Jersey : Prentice Hall.

${ }^{16}$ Anderson, James E. 1984. Public Policy Making. New York: Holt, Rinehart and Winston.
} 
teknologi komunikasi yang dikembangkan bagi kesejahteraan tenaga sosial ${ }^{17}$.

Sementara itu, PLD berfokus pada pendidikan ABK. Selain pendidikan, di dalamnya tentu ada konseling, baik bagi ABK maupun keluarga $A B K$ yang merupakan pendamping di setiap tahap intervensi pemerintah pada program tersebut. Konseling merupakan bentuk komunikasi antar pribadi secara intensif ${ }^{18}$. Harapannya, klien mendapat pencerahan sekaligus arahan yang objektif dari persoalan yang tengah didiskusikan ${ }^{19}$. Dalam konteks program PLD yang dijalankan ini, ada dua yang dikonseling, yakni, ABK dan keluarga. Utamanya, ABK yang kekhususannya masih memungkinkan baginya untuk berdiskusi dengan konselor. Kalau ABK dianggap memiliki kekhususan yang tidak memungkinkan untuk berbincang secara mendalam, konseling langsung dilakukan pada keluarga saja. Sebagai catatan, ABK memiliki tingkat dan jenis kekhususan. Konseling dilaksanakan untuk memastikan intervensi seperti apa yang perlu dijalankan.

Terdapat sejumlah tujuan dari implementasi kebijakan publik PLD. Antara lain, mewujudkan keadilan kesejahteraan dan kesehatan sosial serta pendidikan, kelompok sasarannya, ABK. PLD bisa menjadi pusat pembelajaran bagi keluarga ABK untuk memahami seluk-beluk kekhususan ABK yang hidup bersama mereka. Sehingga, penanganan ABK yang dilakukan keluarga dapat lebih menyeluruh. Bagi ABK, PLD dapat menjadi ruang pendidikan maupun pembinaan fisik dan mental mereka. Masing-masing ABK yang diintervensi memiliki pola intervensi, pendidikan, pembinaan, terapi, bahkan terapi yang berbeda-beda sesuai kebutuhan.

\footnotetext{
${ }^{17}$ Rio Febriannur Rachman. 2019. “Optimalisasi Teknologi Komunikasi Informasi Command Center Bagi Efektifitas Tenaga Kesejahteraan Sosial Kecamatan". Dakwatuna: Jurnal Dakwah dan Komunikasi Islam, 5 (2), 72-81 ${ }^{18}$ Arintoko, Wawancara Konseling Di Sekolah, (Yogyakarta: ANDI, 2011),1

${ }^{19}$ Farid Mashudi, Psikologi Konseling, (Yogyakarta: IRCiSoD, 2012), 19
} 
Bertolak dari perspektif yang dipaparkan Bromley dalam Tachjan ${ }^{20}$, kebijakan publik memunyai tiga tingkat struktural. Antara lain,policy level, organizational level, dan operational level. Di negera demokrasi, termasuk di Indonesia, policy levelumumnya diperankan oleh yudikatif dan legislatif. Sementara itu, organizational leveldiperankan oleh eksekutif. Sedangkan operational level dijalankan oleh perangkat-perangkat yang merupakan alat eksekutif. Misalnya, di level Pemerintah Pusat, perangkat yang dimaksud adalah kementerian, di level Pemerintah Provinsi, perangkat itu berwujud Biro, Dinas, dan sebagainya. Sementara pada ruang lingkup Pemerintah tingkat II atau Kabupaten/Kota, perangkat pemerintah biasanya berupa dinas, bagian, badan, dan lain sebagainya.

Semua kebijakan didasari maupun dilindungi, serta diwujudkan melalui regulasi mengikat atau institutional arrangement. Sejumlah pakar kebijakan publik, menyebutkan soal pattern interaction dalam pelaksanakan kebijakan. Yakni, pola interaksi antara pelaksana lapangan (street level bureaucrat) atau perangkat pemerintah, dengan kelompok yang menjadi target atau sasaran kebijakan. Dampak atau kebermanfaatan dari kebijakan publik, salah satunya, dapat dilihat dari bagaimana pola ini diimplementasikan. Program PLDdijalankan pemerintah di tingkat Kota Surabaya. Dengan kata lain, masing-masing pihak pelaksana berasal dari yudikatif, legislatif, maupun eksekutif dan perangkat, di level kota.

Seperti yang sempat disinggung, PLD dijalankan dengan sistem "jemput bola". Perangkat Pemerintah Kota Surabaya, baik Dinas Pendidikan maupun Kelurahan-kelurahan, turun ke lapangan guna menjalankan sosialisasi program. Termasuk, melakukan pelacakan soal ABK mana yang perlu diintervensi. Dalam pelaksanaannya, Wali Kota Surabaya tidak sekadar berposisi sebagai inisiator program. Lebih dari itu, Wali Kota terus melihat perkembangan PLD dari waktu ke waktu. Evaluasi dilaksanakan secara berjenjang. Yang pada ujung teratas level

20Tachjan. Implementasi Kebijakan Publik. Bandung: AIPI, 2006. 
hirearkis, Wali Kota Surabaya aktif memantau. Tentu saja, dibantu secara sinergis oleh pihak DPRD Surabaya selaku perwakilan masyarakat. Selama ini, layanan bagi mereka yang berkebutuhan khusus memang menjadi salah satu prioritas yang terus dievaluasi dan diperbaiki oleh Pemerintah Kota Surabaya ${ }^{21}$.

PLD sendiri mengalami pemantauan harian oleh Kasi, Kabid, maupun Kepala Dinas Pendidikan Surabaya. Terdapat pula laporan bulanan yang masuk ke meja Wali Kota, dan tentu saja penyampaian program tahunan secara terbuka di gedung DPRD. Indikator yang digunakan dalam evaluasi, antara lain, jumlah layanan atau kegiatan yang dilaksanakan. Sehingga, diketahui apa saja program yang perlu dibenahi atas saran atau aspirasi warga. Dilihat pula animo atau jumlah klien. Para klien, dalam hal ini ABK dan keluarga, juga diminta saran dan masukannya. Evaluasi biasanya berkaitan erat dengan pengembangan kualitas maupun kuantitas layanan di masa yang akan datang.

Kebijakan ini juga berangkat dari keinginan menciptakan lingkungandengan nilai kesetaraan, kebersamaan, dan kekeluargaan. Terdapat upaya menggerus diskriminasi atau menembus disparitas sosial antara mereka yang berkebutuhan khusus dan tidak berkebutuhan khusus. Pola semacam ini selaras dengan prinsip dalam ajaran Islam yang humanis secara alamiah, tanpaperasaan individualitas maupun merasa lebih mulia atau lebih sempurna dibandingkan yang lain. PLD menjadi lebih kuat posisinya dan dapat dijalankan pada waktu-waktu yang akan datang, sehingga terwujud kontinuitas, karena sejak 2016 telah ada slot pendanaan di APBD. Artinya, ada kekompakan antara pihak Pemerintah Kota Surabay dan DPRD Surabaya untuk menjaga keberlangsungan program. Tentu saja, apresiasi positif dari masyarakat, termasu berupa kritik dan saran konstruktif, serta dorongan dari elemen-elemen yang

\footnotetext{
${ }^{21}$ Republika.co.id. 2019. "Pemkot Surabaya Siap Benahi Fasilitas Disabilitas". Dapat diakses di https://republika.co.id/berita/q1xqdp366/pemkot-surabaya-siap-benahi-fasilitas$\underline{\text { disabilitas }}$
} 
paham dengan pendidikan maupun $\mathrm{ABK}$, terus diharapkan. Sehingga PLD dapat menjadi lebih baik dair hari ke hari. Kepuasaan masyarakat target sasaran, baik ABK maupun keluarga, yang disampaikan pada pihak PLD, menjadi motivasi tersendiri bagi Pemerintah Kota Surabaya.

Sejumlah intelektual Islam, baik klasik maupun kontemporer, kerap mengemukakankonsep maqâsid al-syarî’ah, yang membahas tentang agama sebagai ajaran yang menggariskan perlindungan agama, jiwa, akal, keturunan, dan harta. Konsep ini juga erat kaitannya dengan pendidikan yang humanis ${ }^{22}$. Islam memastikan bahwa pendidikan yang baik dan berkualitas, serta merata bagi semua elemen masyarakat merupakan bentuk perwujudan religiusitas dan hubungan vertikal manusia dengan Tuhan Yang Mahaesa ${ }^{23}$.

Bila dirinci, PLD melindungi jiwa dan akal para ABK. Melalui, program ini mereka diposisikan setara dengan anak lain yang tidak berkebutuhan khusus. Tidak ada diskriminasi. Keluarga mereka juga bisa lebih percaya diri untuk terus memberi dukungan pada para ABK. Apabila problem psikologis yang selama ini menggelayut mendapat solusi dari PLD, artinya program ini turut menjaga sarana tumbuhnya keyakinan manusia terhadap kasih sayang Tuhan Yang Mahaesa yang terus memberi jalan keluar bagi segala kesukaran. Sementara itu, bila ditelaah secara objektif di unsur kebermanfaatannya,PLD tergolong sukses.

PLD berhasil memupuk kepedulian antar sesama, karena uang pajak dari masyarakat Surabaya, disalurkan untuk kebutuhan pendidikan yang tidak diskriminatif. Sehingga, melalui atensi besar masyarakat dan inovasi Pemerintah Kota Surabaya, ABK memeroleh hidup yang lebih berkualitas. Pada bagian lain, terdapat pula pembelajaran tentang sikap

\footnotetext{
22Wasehudin, W., 2018. “Menggagas Nilai-Nilai Pendidikan Humanis Dalam Maqasid Al-Syari'ah". Tazkiya, 19(02), halaman 68-79.

${ }^{23}$ Rasyid, M.H., 2015. "Konsep Pendidikan Islam Dalam Maqasid Al-Syari'ah". AshShahabah, 1(2), halaman 1-9.
} 
saling menghargai satu sama lain. Ada pemahaman tentang potensipotensi terpendam yang dimiliki semua manusia, bagaimana pun kondisinya. Mereka yang berkebutuhan khusus, bila ditangani secara pas, bisa jadi minat dan bakat dapat disalurkan. PLD juga hadir untuk menggali kemungkinan-kemungkinan itu melalui tahapan konseling dan assement berkelanjutan. Pembelajaran sehubungan dengan sinergitas juga hadir melalui PLD. Sebab, program ini hanya dapat terwujud dengan kolaborasi apik antara petugas PLD, ABK, keluarga ABK, serta asosiasiasosiasi atau para pakar yang tak bosan diajak mendiskusikan persoalan ABK kekinian.

\section{MewujudkanPembangunan Sosial Demi Kemaslahatan Umat}

Pada 2015 lalu, Perserikatan Bangsa-Bangsa menggariskan tujuh belas poin tujuan pembangunan sosial berkelanjutan24. Apa yang ditetapkan itu bertujuan untuk mewujudkan masyarakat yang lebih baik di masa datang.Semua pemimpin pemerintahan di dunia diarahkan agar membuat program-program yang selaras dengan tujuan belas poin tersebut. Poin pertama, No Poverty atau menggerus kemiskinan. Jadi, program yang dilakukan pemerintah mesti memiliki tujuan menghilangkan kemiskinan.

Poin kedua, Zero Hunger atau mewujudkan dunia tanpa kelaparan dan mencapai ketahanan di bidang pangan. Yang ketiga, Good Health and Well-Being atau berupaya menciptakan kehidupan sehat di segala lini, serta mendukung kesejahteraan bagi masyarakat luas. Keempat, Quality Education atau memberikan pendidikan bermutu. Kebijakan publik di bidang pendidikan yang dijalankan pemerintah seharusnya punya mutu terbaik agar masyarakat bisa bersaing di ranah global.

\footnotetext{
${ }^{24}$ Perserikatan Bangsa-Bangsa. 2015. About the Sustainable Development Goals. Tersedia di https://www.un.org/sustainabledevelopment/sustainable-development-goals/.

Diakses pada 11 September 2018
} 
Kelima, adanya semangat Gender Equality atau kebijakan berorientasi kesetaraan gender. Tidak boleh ada diskriminasi berbasis gender. Keenam, mewujudkan Clean Water and Sanitation atau ketersediaan air bersih dan sanitasi yang baik demi menciptakan Sumber Daya Manusia berkualitas. Ketujuh, memastikan keterjangkauan akses pada energi yang dibutuhkan kehidupan, atau Affordable and Clean Energy. Kedelapan, Decent Work and Economic Growth, dengan kata lain, kebijakan publik perlu berazaskan cita-cita akan pertumbuhan ekonomi berkelanjutan. Yang sudah barang tentu punya hubungan dengan terwujudnya lapangan pekerjaan yang layak bagi masyarakat.

Kesembilan, merealisasikan Industry, Inovation and Infrastructure yang sehat. Dengan cara ini, diharapkan, kesejahteraan masyarakat bisa merata. Kesepuluh, mereduksi ketidaksetaraan atau Reduced Inequalities. Kesenjangan sosial harus terus dipangkas. Kesebelas, atau menciptakan kota dan komunitas yang hidup berkelanjutan dengan layak, atau Suistanable Cities and Communities.

Kedua belas, membentuk pola konsumsi dan produksi yang baik dan berkesinambungan atau Responsible Consumption and Production. Ketiga belas, berorientasi pada perubahan iklim atau Climate Action. Kebijakan publik sepantasnya mengambil peran pada upaya membendung dampak buruk perubahan iklim. Karena, memiliki korelasi dengan keselamatan dunia. Keempat belas, memerhatikan kehidupan di perairan atau Life Below Water. Pengelolaan perairan atau sumber daya air, baik danau, sungai, laut, samudra dan segala sektor kemaritiman. Kelima belas, memanfaatkan dan mengelola sumber daya di daratan atau Life on Land.

Keenam belas, menguatkan institusi, khususnya pemerintah, demi Peace, Justice, and Strong Institutions. Yang pada gilirannya, akan berdampak positif pada keadilan di masyarakat. Ketujuh belas, adanya Partnership for The Goals atau kemitraan baik antar institusi dalam satu 
negara, maupun antar institusi global. Tujuannya, merealisasikan pembangunan yang berkelanjutan yang merata.

Program PLD selaras dengan tujuan pembangunan berkelanjutan yang digariskan PBB tersebut. Perlu dipahami, konsep ini tidak berarti bahwa satu kebijakan mesti sesuai dengan tujuh belas poin. Melainkan, paling tidak satu poin PBB tersebut ada dalam satu kebijakan pemerintah yang diimplementasikan. Lebih banyak poin yang diperhatikan, tentu jauh lebih baik.

Program PLD ini senada dengan cita-citaGood Health and Well-Being atau keterjaminan kesehatan dan hidup yang baik. Dengan pendidikan dan pembinaan yang baik bagi anak-anak berkebutuhan khusus, kesehatan dan kehidupan mereka akan menjadi lebih baik. Kesehatan dan kehidupan sehari-hari mereka pun akan terus terpantau. Baik yang sifatnya jasmani, maupun ruhani yang berhubungan dengan mental.

Keberadaan program PLD ini selaras juga dengan poinQuality Education. Yang titik beratnya adalah memberikan pendidikan bermutu bagi semua lapisan masyarakat, dari semua latar belakang. PLD memberikan jaminan pendidikan bermutu dan pembinaan berkelanjutan bagi anak-anak berkebutuhan khusus. PLD juga hadir sebagai bentuk program mengurangi kesenjangan, yang berkesesuaian dengan poin Reduce Inequality. Dalam kasus ini, di antara anak-anak yang tidak berkebutuhan khusus dan anak-anak berkebutuhan khusus, sama-sama diberi atensi maksimal oleh pemerintah. Tidak ada perbedaan dalam memberikan layanan pendidikan bagi mereka yang berkebutuhan khusus.

Melalui cara ini pula, PLD ikut menjaga keberlangsungan kota dan komunitas yang ada di dalamnya. Dengan kata lain,program ini selaras dengan semangatSustainable Cities and Communities yang digariskan PBB. PLD ingin memastikan kelompok anak-anak berkebutuhan khusus dapat menikmati pendidikan, kehidupan, dan lingkungan yang sejahtera, dan 
berbahagia. Mereka diberi akses untuk menikmati fasilitas pendidikan dasar di kota Surabaya.

PLD juga merupakan bentuk dari poin Peace, Justice, and Strong Institutions. Gamblangnya, Pemerintah Kota Surabaya ingin menebar kedamaian, keadilan sosial, melalui kebijakan yang kuat dan dapat dipertanggungjawabkan. Realisasi kedamaian dan keadilan akan membuat pemerintah daerah cenderung lebih mudah dipatuhi regulasinya oleh masyarakat setempat.

Pemerintah Kota Surabaya tidak menjalankan program ini sendirian, melainkan terdapat bangunan kerjasama dengan pihak lain. Misalnya, dengan asosiasi yang mengkoordinasikan para terapis bagi anak-anak berkebutuhan khusus. Asosiasi ini berpusat di RSUD dr Soetomo Surabaya. Sejatinya, para petugas PLD memiliki keahlian dalam penanganan anak-anak berkebutuhan khusus. Meski demikian, tetap saja mereka butuh untuk terus belajar dengan pakar-pakar lain. Termasuk, dari asosiasi ini. Guna menambah wawasan dan pengetahuan, apalagi, persoalan anak-anak berkebutuhan khusus sering berkembang dan variatif.

Terdapat pula sinergi dengan pihak DPRD yang merupakan pengawas program. Inovasi PLD terselenggara dengan gelontoran dana APBD Surabaya atau uang rakyat, yang tentu saja mesti disetujui dulu oleh DPRD. Wakil rakyat pasti memantau dan memberi masukan pada program ini. Pihak lain yang juga punya andil adalah media massa atau pers sebagai kontrol sosial

Perjuangan untuk memberikan pendidikan dasar berkualitas dan pembinaan bagi anak-anak berkebutuhan khusus harus dilakukan secara sinergis. Apalagi, tujuan utama PLD adalah mewujudkan kemaslahatan umat atau kesejahteraan masyarakat luas di segala lapisan masyarakat. Meskipun memang, kelompok sasarannya adalah mereka yang berkebutuhan khusus. Namun, program ini merupakan faktor penting 
untuk keadilan pendidikan yang lingkupnya luas. Tanpa program ini, keadilan pendidikan di Surabaya perlu dipertanyakan.

Pelaksanaan program dilakukan dengan saling bergandeng tangan, dan hal ini senada dengan makna kebersamaan yang terdapat pada sejumlah dalil Al Quran. Sebagai contoh, di Surat Ash-shof ayat 4: Sesungguhnya Allah menyukai orang yang berjuang di Jalan-Nya dalam barisan yang teratur seakan-akan mereka seperti suatu bangunan yang tersusun kokoh.

Konsep berjuang dalam ayat ini tidak sebatas soal peperangan dan barisan yang dimaksud tidak melulu barisan angkatan bersenjata. Lebih luas dari itu, perjuangan yang dimaksud merupakan usaha mewujudkan kemaslahatan umat dan memberikan manfaat bagi sebanyak-banyaknya manusia. Senafas dengan salah satu riwayat yang menyebutkan: Wajib atas kaum muslimin bersama dalam Al-Jamaah dan berhati-hati pada perpecahan (HR At-Tirmidzi). Bila dipandang dari konteks kekinian, AlJamaah bisa dipersepsikan sebagai kebersamaan dalam sebuah gerakan yang bercita-cita mewujudkan kemaslahatan umat. Kebijakan yang berlangsung karena adanya sinergi telah menjadi kekhasan dari kegiatan di Pemerintah Kota Surabaya, dalam segala bidang. Sebagai contoh, di bidang pengembangan industri kreatif dan optimalisasi media digital yang dijalankan dalam program Co-Working Space di Koridor Jalan Tunjungan ${ }^{25}$.

\section{Kesimpulan}

Keberhasilan berjalannya kebijakan publik umumnya bisa dilihat dari tiga aspek ${ }^{26}$. Pertama, adanya kepatuhan (compliance) dari objek implementasi kebijakan. Kedua, konsistensi program dan komplain yang minimal terhadap kebijakan. Ketiga, hasil dari program yang bisa

\footnotetext{
${ }^{25}$ Rio Febriannur Rachman. 2019. "Pengembangan Industri Kreatif Berbasis Media

Digital di Surabaya dalam Perspektif Islam". Komunitas. 10(2), 157-176.

${ }^{26}$ Randall B. Ripley \& Grace A. Franklin. 1986. Policy Implementation and Bureaucracy.

Chicago: The Dorsey Press.
} 
dipertanggungjawabkan dan memuaskan semua pemangku kepentingan. Terutama, pihak yang menerima manfaat dari program kebijakan tersebut.

Bila mengacu pada teori di atas, program PLD yang dijalankan Dinas Pendidikan Pemerintah Kota Surabaya tergolong berjalan dengan lancar. Ada sejumlah fakta yang menguatkan persepsi tersebut. Pertama, ada kepatuhan masyarakat penerima manfaat terhadap program PLD. Tidak ada keluhan dari masyarakat, sehingga program yang digariskan Pemerintah Kota Surabaya bisa dijalankan dengan optimal, dan disesuaikan dengan kebutuhan masyarakat. Dinas Pendidikan sebagai pelaksanakan kegiatan di lapangan, otomatis pula patuh pada inisiator kebijakan atau Wali Kota. Kedua, terdapat konsistensi program dan komplain yang minimal. Artinya, Dinas Pendidikan konsisten sebagai pelaksana program, salah satunya karena sudah melihat kalau program ini telah bisa bertahan dan didukung masyarakat.

Ketiga, program di PLD bisa dipertanggungjawabkan, dan telah berjalan sejak 2016 tanpa kendala berarti. Meski memang, pembenahan program demi makin memberikan pelayanan prima terus dilaksanakan pula. DPRD selaku pengawas program juga tidak mengusulkan untuk menghentikan PLD. Artinya, PLD dapat diterima masyarakat. Terlebih, program ini juga terbukti selaras dengan tujuan pembangunan sosial berkelanjutan yang dicanangkan PBB dan nilai-nilai kemaslahatan umat yang digariskan oleh ajaran Islam.

Yang jelas, PLD dapat berjalan dengan konsisten dan baik selama ini, karena Surabaya memiliki modal di aspek keuangan, sosial, budaya, serta regulasi kelembagaan yang mengikat. Di aspek keuangan, APBD kota ini kuat untuk menopang semua kegiatan PLD. Di aspek sosial, masyarakat jelas mendukung program yang merupakan bentuk kepedulian terhadap sesama. Di aspek budaya, masyarakat Surabaya kompatimbel dengan program yang menunjukkan kerukunan antara 
semua lapisan masyarakat dari berbagai latar belakang. Termasuk di dalamnya, mendukung program-program yang berbasis kepedulian sosial. Karena program semacam ini pas dengan kultur dan lingkungan masyarakat Surabaya.

PLD juga ditopang oleh sejumlah regulasi, baik Peraturan Daerah maupun Peraturan Wali Kota dan SK Wali Kota. Tentu saja, Peraturan Daerah tentang APBD tahunan. Ada pula Perda, Perwali, dan SK Wali Kota yang menjadi penguat berjalannya PLD. Di antaranya, Peraturan Daerah Kota Surabaya Nomor 2 Tahun 2017 tentang Upaya Kesehatan yang di dalamnya disampaikan pula soal atensi pada anak-anak berkebutuhan khusus. Semua fakta tadi memerlihatkan keseriusan Pemerintah Kota Surabaya dalam menjalankan program pendidikan dasar dan pembinaan anak-anak berkebutuhan khusus.

Yang menarik, PLD dapat dijalankan atau direplikasi oleh Pemerintah Daerah lain. Syaratnya, ada keinginan yang kuat dan konsistensi dari pemerintah daerah maupun masyarakat sebagai pendukung kebijakan, di antaranya dari elemen DPRD Surabaya. Yang tak kalah penting, ketersediaan dana APBD untuk operasional kegiatan. Terlebih, PLD merupakan implementasi Undang-Undang di aspek pendidikan dasar. Selama ini, terdapat pemerintah daerah maupun DPRD dari wilayah lain yang datang ke Dinas Pendidikan Surabaya ${ }^{27}$. Dalam kesempatan itu, dijelaskan pula soal kebijakan PLD pada mereka. Ini merupakan bentuk keterbukaan Dinas Pendidikan Surabaya demi mewujjudkan kesejahteraan bagi masyarakat dalam lingkup yang lebih luas.

\section{Daftar Pustaka}

Anderson, James E. 1984. Public Policy Making. New York: Holt, Rinehart and Winston.

\footnotetext{
${ }^{27}$ Liputan6.com. 2019. “Pemkot Surabaya Gelar Pameran Pendidikan Sekolah Berprestasi". Dapat diakses di https://surabaya.liputan6.com/read/4100954/pemkotsurabaya-gelar-pameran-pendidikan-sekolah-berprestasi
} 
Arintoko. 2011. Wawancara Konseling Di Sekolah. Yogyakarta: ANDI,1

Bagian Organisasi Pemerintah Kota Surabaya. 2019. “Pulau Emas”. Dapat diakses https://organisasi.surabaya.go.id/home/file/pelayanan $\% 20$ publik/ masuk\%20web/proposal\%20pulau\%20emas.pdf

Dye, Thomas R. 1972. Understanding Public Policy. New Jersey : Prentice Hall.

Ghulam, Zainil. 2020. “Implementasi Kebijakan Magang Dan Konseling Warga Berkebutuhan Khusus Di Surabaya". Dakwatuna: Jurnal Dakwah dan Komunikasi Islam, 6, (1), halaman 75-87,

Jawa Pos. 2017. “Bentuk Pelayanan Khusus Buat Penyandang Disabilitas”. Dapat diakses

https://www.jawapos.com/nasional/pendidikan/07/02/2017/bent uk-pelayanan-khusus-buat-penyandang-disabilitas/

Kholis, Nur. 2013. "Pendidikan dalam upaya memajukan teknologi", Jurnal kependidikan, Vol 11, No. 1, November, 24.

Liputan6.com. 2019. "Pemkot Surabaya Gelar Pameran Pendidikan Sekolah Berprestasi". Dapat diakses di https://surabaya.liputan6.com/read/4100954/pemkot-surabayagelar-pameran-pendidikan-sekolah-berprestasi

Mahsun, Moch \& Danish Wulydavie Maulidina. 2019. “Konsep Pendidikan Dalam Kitab Ta'limul Muta'allim Karya Syekh AlZarnuji Dan Kitab Washoya Al-Aba' Lil-Abna' Karya Syekh Muhammad Syakir". Bidayatuna: Jurnal Pendidikan Guru Mandrasah Ibtidaiyah, 2 (2), halaman 44-77

Mashudi, Farid. 2012. Psikologi Konseling, Yogyakarta: IRCiSoD, 19

Perserikatan Bangsa-Bangsa. 2015. About the Sustainable Development Goals. Tersedia https://www.un.org/sustainabledevelopment/sustainabledevelopment-goals/. Diakses pada 11 September 2018

Rachman, Rio Febriannur. 2019. “Optimalisasi Teknologi Komunikasi Informasi Command Center Bagi Efektifitas Tenaga Kesejahteraan Sosial Kecamatan". Dakwatuna: Jurnal Dakwah dan Komunikasi Islam, 5 (2), 72-81 
Rachman, Rio Febriannur. 2019. “Optimalisasi Media Digital Berbasis Kemaslahatan Umat dalam Program Pahlawan Ekonomi Surabaya".Iqtishoduna: Jurnal Ekonomi Islam, 8 (2), 273-292

Rachman, Rio Febriannur. 2019. “Implementasi Kebijakan Pusat Konseling Anak Dan Remaja Di Surabaya". Al-Tazkiah : Jurnal Bimbingan Dan Konseling Islam, 8(2), 77-91

Rachman, Rio Febriannur. 2019. “Pengembangan Industri Kreatif Berbasis Media Digital di Surabaya dalam Perspektif Islam”. Komunitas,10(2), 157-176.

Rasyid, M.H., 2015. "Konsep Pendidikan Islam Dalam Maqasid AlSyari'ah". Ash-Shahabah, 1(2), halaman 1-9.

Republika.co.id. 2019. "Pemkot Surabaya Siap Benahi Fasilitas Disabilitas". Dapat diakses di https://republika.co.id/berita/q1xqdp366/pemkot-surabaya-siapbenahi-fasilitas-disabilitas

Ripley, Randall B. \& Grace A. Franklin. 1986. Policy Implementation and Bureaucracy. Chicago: The Dorsey Press.

Roqib, Moh. 2005. Ilmu pendidikan Islam, Yogyakarta: Lkis, 14.

Soardi, Moh. dkk, 2017, Dasar-dasar pendidikan, Yogyakarta:PT. Parama Ilmu, 50.

Soedarso, et al. Dinamika Multikultural Masyarakat Kota Surabaya. Jurnal Sosial Humaniora 6.1 (2013): 62-75.

Sudandi, 2015, Pengantar studi Islam, Yogyakarta:Media Tera, 154.

Surabaya.go.id. 2018. "PLD Lima Wilayah untuk Tingkatkan Layanan Pendidikan Inklusi". Dapat diakses di https://surabaya.go.id/id/berita/46197/pld-lima-wilayah-upayatingkatk

Tachjan. 2006. Implementasi Kebijakan Publik. Bandung: AIPI

Wasehudin, W., 2018. "Menggagas Nilai-Nilai Pendidikan Humanis Dalam Maqasid Al-Syari'ah". Tazkiya, 19(02), halaman 68-79.

Zed, M. (2008). Metode Penelitian Kepustakaan. Jakarta: Yayasan Pustaka Obor Indonesia. 